\title{
Pengaruh Konsentrasi Dan Waktu Aplikasi Pupuk Organik Cair Nasa Terhadap Pertumbuhan Dan Produksi Tanaman Jagung Manis Pada Tanah Sawah
}

\author{
Zulkarnain Sangadji \\ Fakultas Pertanian Universitas Muhammadiyah Sorong \\ Zulkarnainums1@gmail.com
}

\begin{abstract}
Exploiting organic liquid fertilizer to lessening use fertilizer inorganic and fertilizer cage can becoming. one the solution in improving production sweet corn by exploiting land rice. Research executed at Waimital village, sub district of Kairatu, sub-Province Seram Part of West. Research take place from Desember 2013 to Maret, 2014. The research was conducted using a randomized block design consisting of no fertilizing ( 0 $\mathrm{ml} / \mathrm{L})$, application of POC $(7.5 \mathrm{ml} / \mathrm{L}, 15 \mathrm{ml} / \mathrm{L}, 22.5 \mathrm{ml} / \mathrm{L}$, and $30 \mathrm{ml} / \mathrm{L})$ and application time $2 \mathrm{MST}\left(\mathrm{W}_{1}\right), 2,4 \mathrm{MST}\left(\mathrm{W}_{2}\right)$, and 2,4,6 MST $\left(\mathrm{W}_{3}\right)$. Each treatment consisted repeated that there are 30 treatment attempt. The result showed that organic liquid fertilizer having an effect on reality to is high crop, wide leaf, long cob, and cob weight. Concentration organic liquid fertilizer $30 \mathrm{ml} / \mathrm{L}$ yielding production cob weight best equal to $271.35 \mathrm{~g} / \mathrm{cob}$. Application time have an effect on reality to is high crop and wide leaf, while cob length and cob weight do not have an effect on reality. Application time times namely : 2,4, and $6 \mathrm{MST}\left(\mathrm{W}_{3}\right)$ the best results in the appeal of other treatments. Best combination shown by treatment concentration $30 \mathrm{ml} / \mathrm{L}$ with application time 3 times namely : 2, 4, and 6 week after planting $\left(\mathrm{N}_{4} \mathrm{~W}_{3}\right)$.
\end{abstract}

Key Words : Organic liquid fertilizer, time application, Sweet Corn.

\begin{abstract}
ABSTRAK
Pemanfaatan pupuk organik cair untuk mengurangi penggunaan pupuk anorganik dan pupuk kandang dapat menjadi salah satu solusi dalam menigkatkan produksi jagung manis dengan memanfaatkan lahan sawah. Penelitian dilaksanakan di Desa waimital, kecamatan Kairatu kabupaten Seram Bagian Barat. Penelitian berlangsung dari bulan Desember 2013 sampai bulan Maret 2014. Penelitian dilaksanakan menggunakan rancangan acak kelompok yang terdiri dari tanpa pemupukan $(0 \mathrm{ml} / \mathrm{L})$, Konsentrasi POC (7.5 ml/L, $15 \mathrm{ml} / \mathrm{L}, 22.5 \mathrm{ml} / \mathrm{L}$, dan $30 \mathrm{ml} / \mathrm{L}$ ) dan waktu aplikasi $2 \mathrm{MST}\left(\mathrm{W}_{1}\right)$, 2 dan 4 MST $\left(\mathrm{W}_{2}\right)$, serta 2, 4, dan 6 MST $\left(\mathrm{W}_{3}\right)$. Setiap perlakuan di ulang 2 kali sehingga terdapat 30 plot percobaan. Hasil penelitian menunjukkan bahwa pupuk organik cair berpengaruh nyata terhadap tinggi tanaman, luas daun, panjang tongkol berkelobot, dan berat tongkol berkelobot. Konsentrasi pupuk organik cair $30 \mathrm{ml} / \mathrm{L}$ menghasilkan produksi berat tongkol berkelobot terbaik sebesar $271.35 \mathrm{~g} /$ tongkol. Waktu aplikasi berpengaruh nyata terhadap tinggi tanaman dan luas daun, sedangkan panjang tongkol berkelobot dan berat tongkol tidak berpengaruh nyata. Waktu aplikasi 3 kali yakni : 2, 4, dan 6 MST $\left(\mathrm{W}_{3}\right)$ menghasilkan pertumbuhan dan produksi terbaik dibandingkan dengan perlakuan lainnya. Kombinasi terbaik ditunjukkan oleh perlakuan konsentrasi $30 \mathrm{ml} / \mathrm{L}$ dengan waktu aplikasi 3 kali yakni : 2, 4, dan $6 \mathrm{MST}\left(\mathrm{N}_{4} \mathrm{~W}_{3}\right)$.
\end{abstract}

Kata Kunci : Pupuk organik cair, waktu aplikasi, jagung Manis. 


\section{PENDAHULUAN}

Pemanfaatan lahan sawah untuk tanaman jagung manis (Zea mays saccharata Linn) setelah pemanenan padi akan berdampak terhadap kesuburan tanah karena terangkutnya unsur hara saat panen dan penggunaan pupuk makro secara kontinyu. Ketersediaan unsur mikro terutama sangat dipengaruhi oleh $\mathrm{pH}$. Menurut Buckman dan Brady (1969) unsur mikro seperti $\mathrm{Fe}, \mathrm{Mn}, \mathrm{Zn}$ dan $\mathrm{Cu}$ lebih tersedia pada tanah $\mathrm{pH}$ dibawah 5.0. Pada $\mathrm{pH}$ di atas 7, 5 unsur Molibden (Mo) lebih tersedia sedangkan Boron (B) tersedia pada $\mathrm{pH}$ sekitar 5.0 sampai 7.0. Unsur makro seprti (N, P, K, Ca, $\mathrm{Mg}$, dan S ) lebih tersedia pada $\mathrm{pH} 6.0$ dan sebaliknya akan mengurangi ketersediaan unsur mikro terurtama $\mathrm{Zu}$ dan $\mathrm{Cu}$.

Pemupukan lewat daun merupakan cara mengatasi tanaman yang kekurangan unsur mikro yang tidak dapat di suplai melalui tanah. Menurut Rosmarkam dan Yuwono (2002) bahwa pemupukan Fe melalui daun dianggap lebih efisien dan efektif apalagi jika pemberiannya bersamaan dengan pupuk mikro lainnya $(\mathrm{Cu}, \mathrm{Mn}$, dan $\mathrm{Zn}$ ). Hal ini terjadi karena tidak adanya interaksi dan reaksi antara $\mathrm{Fe}$ dan senyawa lain seperti yang terjadi bila di berikan berupa pupuk lewat tanah.

Pupuk Organik Cair Nasa (POC Nasa) merupakan salah satu pupuk daun bisa dijadikan alternatif karena mengandung unsur makro, mikro, dan zat perangsang tumbuh serta dapat mengurangi penggunaan pupuk kandang karena kandungan 1 botol $(0.5$ liter) POC Nasa setera dengan 0.5 ton pupuk kandang mikro, sedangkan kandungan unsur makro pada POC Nasa lebih sedikit bandingkan pupuk kandang (PT. Nasa, 2005). Selain itu
POC Nasa juga dapat diberikan pada tanah untuk memperbaiki kesuburan tanah.

Jagung manis merupakan salah satu komoditi pangan yang dibudidayakan karena harga jual di pasaran relative lebih tinggi dari jagiung biasa baik di pasar tradisional dan modern. Jagung manis merupakan salah satu jagung yang digolonkan berdasarkan endosrpermanya, dimana endosperma jagung manis memiliki kadar gula (pati) yang lebih tinggi Dan keriput pada saat kering (Setiawan, 2003). Produksi jagung pada tahun 2013 sebesar 18.51 juta ton pipilan kering atau turun sebesar 0.08 juta ton (4.54 \%) dibanding tahun 2012. Penurunan produksi terjadi karena adanya penurunan luas panen sebesar 137.43 ribu hektar (BPS, 2014). Sedangkan produksi jagung di Maluku 2013 sebesar 16.932 ton atau turun 7.38 ton dari tahun 2012 sebesar 18.281 ton (BPS, 2014). Oleh karena itu, produksi tanaman jagung perlu di tingkatkan dengan pemanfaatan lahan sawah setelah pemanenan padi.

Aplikasi pemupukan yang tidak berimbang dalam satu sistem tanam padi-jagung di lahan sawah tadah hujan akan mempengaruhi dinamika hara $\mathrm{N}$, $\mathrm{P}$, dan $\mathrm{K}$ dalam tanah karena dalam satu sistem tanam padi-jagung pupuk yang diaplikasikan ke tanah tidak seluruhnya di manfaatkan oleh tanaman. Nitrogen hanya dapat diserap 55-60\% (Patrick dan Ready 1976), P sekitar 20\% (Hangin dan Tucker 1982; Goswani et al. 1990), K antara 50-70 \% (Tisdale et al. 1985), dan $\mathrm{S}$ diserap sekitar 33\% (Morris 1987). Apabila residu pupuk pada pertanaman sebelumnya tidak diperhitungkan, maka akan terjadi akumulasi hara yang dapat menyebabkan ketidak seimbangan hara dalam tanah. Akumulasi hara $\mathrm{P}$ dapat menyebabkan defisiensi hara $\mathrm{Zn}$, 
akumulasi hara $\mathrm{K}$ akan menyebabkan terganggunya serapan hara $\mathrm{Ca}$, dan akumulasi hara $\mathrm{S}$ akan menyebabkan perubahan $\mathrm{pH}$ tanah (Munawar. 2011).

Aplikasi atau cara pemberian pupuk merupakan suatu konsekuensi penting dari penggunaan berbagai macam jenis pupuk (padat dan cair). Terdapat beberapa cara aplikasi pupuk, salah satunya pupuk lewat daun. Pemberian pupuk lewat daun memberikan reaksi lebih cepat dan efektif untuk menanggulangi kekurangan unsur mikro. Pada dasarnya pemupukan melalui daun dilakukan untuk mengatasi defisiensi unsur hara pada tanaman. Hasil penelitian menunujukkan bahwa POC Nasa $10 \mathrm{cc} / \mathrm{lt}$ air yang diberikan 5 hari sekali meningkatkan bintil akar dan produksi bahan kering tanaman siratro (Husin , 2012).

Berkaitan dengan hal tersebut, pemupukan merupakan salah satu cara yang terus dilakukan untuk meningkatkan produksi tanaman baik melalui tanah maupun lewat daun. Penelitian tentang Pupuk Organik Cair (POC) Nasa masih sangat kurang sehingga peneliti tertarik untuk menganalisis seberapa besar pengaruh POC Nasa terhadap terhadap perubahan sifat kimia Tanah, pertumbuhan dan produksi jagung manis yang dikombinasikan waktu aplikasi.

Tujuan dari penelitian adalah untuk Mengalisis pengaruh konsentrasi dan waktu aplikasi pupuk organik cair nasa terhadap pertumbuhan dan produksi tanaman jagung manis.

\section{BAHAN DAN METODA PENELITIAN}

Penelitian ini telah dilaksanakan pada lahan sawah petani di Desa Waimital (Gemba) Kecamatan Kairatu Kabupaten Seram Bagian Barat.
Penelitian dilaksanakan kurang lebih selama 3 bulan.

Metode Penelitian menggunakan metode eksperimen dimana, faktor pertama yang diuji adalah 5 taraf konsentrasi pupuk organik cair Nasa di tambah 1 kontrol sebagai berikut :

No $=$ KONTROL

$\mathrm{N} 1=$ Konsentrasi $7.5 \mathrm{ml} / \mathrm{L}$ air $/$ plot

$\mathrm{N} 2=$ konsentrasi $15 \mathrm{ml} / \mathrm{L}$ air $/$ plot

$\mathrm{N} 3$ = konsentrasi $22.5 \mathrm{ml} / \mathrm{L}$ air/ plot

$\mathrm{N} 4$ = konsentrasi $30 \mathrm{ml} / \mathrm{L}$ air/ plot

Faktor kedua yang diuji adalah

3 taraf waktu aplikasi pupuk organik cair nasa yaitu :

$\mathrm{W}_{1}=$ Aplikasi 1 kali pada umur 2 Minggu Setelah Tanam (MST)

$\mathrm{W}_{2}=$ Aplikasi 2 kali pada umur 2 dan 4 MST

$\mathrm{W}_{3}=$ Aplikasi 3 kali pada umur 2, 4, dan 6 MST

Perlakuan yang diuji tersebut menggunakan percobaan faktorial dalam Rancangan Acak Kelompok (RAK) (Gaspers,. 1991). Kombinasi perlakuan sebagai berikut :

Dengan demikian terdapat 15 $\begin{array}{lllll}\mathrm{N}_{0} \mathrm{~W}_{1} & \mathrm{~N}_{0} \mathrm{~W}_{2} & \mathrm{~N}_{0} \mathrm{~W}_{3} & \mathrm{~N}_{1} \mathrm{~W}_{1} & \mathrm{~N}_{1} \mathrm{~W}_{2}\end{array}$

$\begin{array}{lllll}\mathrm{N}_{1} \mathrm{~W}_{3} & \mathrm{~N}_{2} \mathrm{~W}_{1} & \mathrm{~N}_{2} \mathrm{~W}_{2} & \mathrm{~N}_{2} \mathrm{~W}_{3} & \mathrm{~N}_{3} \mathrm{~W}_{1}\end{array}$

$\begin{array}{lllll}\mathrm{N}_{3} \mathrm{~W}_{2} & \mathrm{~N}_{3} \mathrm{~W}_{3} & \mathrm{~N}_{4} \mathrm{~W}_{1} & \mathrm{~N}_{4} \mathrm{~W}_{2} & \mathrm{~N}_{4} \mathrm{~W}_{3}\end{array}$ perlakuan, dimana masing-masing perlakuan di ulang sebanyak 2 kali sehingga terdapat 30 satuan percobaan. Model matematika untuk rancangan yang digunakan adalah :

$\mathrm{Y}_{\mathrm{ijk}}=\mu+\mathrm{K}_{\mathrm{i}}+\alpha_{\mathrm{j}}+\beta_{\mathrm{k}}+(\alpha \beta)_{\mathrm{jk}}+\varepsilon_{\mathrm{ijk}}$

Keterangan :

$\mathrm{Y}_{\mathrm{ijk}}=$ Respon tanaman jagung manis yang diamati

$\mu=$ Rata-rata Umum

$\mathrm{K}_{\mathrm{i}}=$ Pengaruh Kelompok ke- $\mathrm{i}$

$\alpha_{j}=$ Pengaruh Taraf ke-j dari faktor pupuk organik cair nasa

$\beta_{\mathrm{k}}=$ Pengaruh taraf $\mathrm{ke}-\mathrm{k}$ dari faktor waktu pemberian pupuk organik cair nasa 
$(\alpha \beta)_{\mathrm{jk}}=$ Pengaruh interaksi taraf kej dari faktor pupuk organik cair nasa dan taraf ke-k dari faktor waktu pemberian pupuk organik cair nasa

$\varepsilon_{\mathrm{ijk}}=$ Pengaruh acak percobaan dari kelompok ke-i, taraf ke-j dari faktor pupuk organik cair nasa dan taraf ke-k dari faktor waktu pemberian pupuk organik cair nasa.

\section{HASIL DAN PEMBAHASAN}

\section{Hasil Dan Pembahasan}

Berdasarkan hasil analisis sidik ragam terlihat nilai Koefisien Keragaman (KK) pada semua parameter tergolong kecil $<20 \%$ untuk percobaan lapangan (Hanafiah, 2003). Sedangkan $\mathrm{R}^{2}$ (Koefisien determinasi) berkisar antara 0.934- 0.996 akibat pengaruh faktor perlakuan terhadap paremeter yang diamati (Gaspers. 1991). Hasil analisis varian untuk semua parameter yang diamati disajikan pada tabel 1.

\begin{tabular}{|c|c|c|c|c|c|c|}
\hline \multicolumn{7}{|c|}{ Perlakuan } \\
\hline No & Parameter & $\begin{array}{c}\text { Nasa } \\
(\mathrm{N})\end{array}$ & $\begin{array}{l}\text { Waktu } \\
\text { (W) }\end{array}$ & $\begin{array}{l}\mathrm{N} \\
\mathrm{X} \\
\mathrm{W} \\
\end{array}$ & KK & $\mathrm{R}^{2}$ \\
\hline 1 & $\begin{array}{l}\text { Tinggi } \\
\text { Tanaman } \\
6 \text { MST }\end{array}$ & $*$ & $*$ & tn & 1.92 & 0.983 \\
\hline 2 & $\begin{array}{l}\text { Luas } \\
\text { Daun } \quad 6 \\
\text { MST }\end{array}$ & $* *$ & $*$ & tn & 5,89 & 0,934 \\
\hline 3 & $\begin{array}{l}\text { Panjang } \\
\text { Tongko }\end{array}$ & $* *$ & tn & tn & 7,14 & 0,940 \\
\hline 4 & $\begin{array}{l}\text { Berat } \\
\text { Tongkol }\end{array}$ & $* *$ & $\operatorname{tn}$ & tn & 0,87 & 0,996 \\
\hline
\end{tabular}

Keterangan : * (beda nyata), **(sangat nyata), tn (tidak nyata), KK (Koefisien Keragaman).

Hasil analisis varian menunjukkan bahwa tidak terjadi interaksi antara konsentrasi POC Nasa (N) dan waktu plikasi (W) untuk semua parameter yang di amati. Hal ini sebabkan masing-masing perlakuan memberikan respon secara terpisah terhadap pertumbuhanan dan produksi jagung manis. Menurut (Hanafiah, 2003) bahwa tipe interaksi ini termasuk dalam tipe interaksi positif di mana factor Konsentrasi POC Nasa dan waktu aplikasi saling menaikan pengaruh. Ditambahkan oleh Gomes \& Gomes (1995), bahwa dua factor dikatakan berinteraksi apabila pengaruh suatu factor perlakuan berubah pada saat perubahan taraf faktor perlakuan lainnya. Selanjutnya dinyatakan juga oleh Steel dan Torie (1991), bahwa bila tidak terjadi interaksi maka dapat disimpulkan bahwa diantara faktor perlakuan tersebut bertindak bebas satu sama lainnya.

\section{Tinggi Tanaman}

Pemberian POC Nasa dengan konsentrasi $30 \mathrm{ml} / \mathrm{L}\left(\mathrm{N}_{4}\right)$ berbeda sangat nyata terhadap konsentrasi $\mathrm{N}_{3}$ $(22.5 \mathrm{ml} / \mathrm{L}$ air $), \mathrm{N}_{2}(15 \mathrm{ml} / \mathrm{L}$ air$)$, $\mathrm{N}_{1}\left(7.5 \mathrm{ml} / \mathrm{L}\right.$ air) dan $\mathrm{N}_{0}$ (tanpa nasa) terhadap tinggi tanaman jagung manis umur 6 minggu setelah tanam. Diduga pemberian POC Nasa dengankonsentrasi $30 \mathrm{ml} / \mathrm{L}$ air $\left(\mathrm{N}_{4}\right)$ berupa hara makro dan mikro yang masuk melalui mulut daun (stomata) dapat dimanfaatkan tanaman selama periode pertumbuhan vegetatif, sehingga mampu memberikan tinggi tanaman terbaik dibandingkan dengan konsentrasi dibawahnya. Hal ini dapat dilihat dari komposisi $\mathrm{N}$ sebesar 0.12 $\%$ yang terkandung pada POC Nasa, dimana unsur Nitrogen (N) yang diberikan lewat daun lebih cepat terserap oleh stomata daun dan dimanfaatkan oleh tanaman dalam proses fotosintesis dengan bantuan sinar matahari. Tetapi, beberapa pakar ilmu fisiologi tanaman menduga bahwa di samping diserap stomata penyerapan unsur hara juga dapat melalui ektodesmata (Marschner, 1986).

Nitrogen adalah unsur hara utama bagi pertumbuhan organ-organ tanaman 
karena merupakan penyusun asam amino, amida dan nukleoprotein yang merupakan unsur penting bagi pembelahan sel. Pembelahan sel yang berlangsung baik akan menunjang pertumbuhan tanaman karena pertumbuhan adalah bertambahnya ukuran, volume, bobot dan jumlah sel. Selain itu Nitrogen berfungsi dalam meningkatkan jumlah klorofil, sehingga apabila $\mathrm{N}$ tersedia dalam jumlah cukup, maka akan meningkatkan laju fotosintesis dan pada akhirnya fotosintat yang terbentuk akan banyak.

Nitrogen diambil akar dalam bentuk ion $\mathrm{NH}_{4}{ }^{+}$dan $\mathrm{NO}_{3}{ }^{-}$. Di dalam tanah, nitrogen bersifat mobil dan mudah mengalami perubahan bentuk (transformasi). Pada kondisi tertentu ia menjadi tidak tersedia karena terikat atau terfiksasi. Perubahanperubahan ini umumnya dilakukan oleh jazad mikro tanah. Beberapa di antaranya jazad mikro spesifik kondisi aerobik atau anaerobik. Aktivitas jazad, di satu pihak menyediakan $\mathrm{N}$ bagi tanaman, tetapi di lain pihak menyebabkan ketidak-tersediaan. Hal ini terlihat pada hasil analsis tanah dimana kandungan $\mathrm{N}$ total tergolong rendah. Dengan pemberian pupuk organik maka dapat meningkatkan ketersediaan $\mathrm{N}$ di dalam tanah Bagi tanaman. Menurut Sangadji, 2009 menyatakan bahwa $\mathrm{N}$ yang diberikan ke tanah melalui pupuk organik dapat menyebabkan kapasitas pertukaran yang tinggi, baik terhadap kation maupun anion sehingga struktur tanah lebih sesuai dan dapat dimanfaatkan oleh tanaman secara langsung. Menurut Latuamury, 2017 yang menyatakan pada tanah dengan kadar bahan organik tinggi, struktur tanahnya lebih baik bila dibandingkan dengan tanah dengan kadar bahan organik rendah.

Kandungan P $(0.03 \%), \mathrm{K}(0.31$ $\%), \mathrm{Mg}(16.88 \mathrm{ppm})$ dan $\mathrm{Cu}(0.03$ ppm) yang terkandung dalam POC Nasa juga turut andil selama fase pertumbuhan vegetativ, pemupukan $\mathrm{N}$ harus diimbangi dengan pemupukan unsur lain. Pembentukan senyawa $\mathrm{N}$ organik tergantung pada imbangan ionion lain, termasuk $\mathrm{Mg}$ untuk pembentukan klorofil dan ion fosfat untuk sintesis asam nukleat. Penyerapan N nitrat untuk sintesis menjadi protein juga di pengaruhi oleh ketersediaan ion $\mathrm{K}^{+}$. $\mathrm{Cu}$ berperan besar dalam fotosintetis sebagai plastosianin pada kloroplas yang berfungsi sebagai pembawa electron pada proses fotosistesis (Lakitan, 2003). $\mathrm{Cu}$ diserap lewat daun dalam bentuk $\mathrm{CuSO}_{4}$.

Kandungan Kalium ( $\mathrm{K}$ tersedia dan $\mathrm{K}$ total ) yang tinggi pada tanah turut mendukung pertumbuhan tanaman. Kalium berperan penting terhadap ketegaran, vigor tanaman, meningkatkan ketahanan tanaman terhadap penyakit tertentu, di samping mendorong perkembangan akar. Menurut Munawar (2011) hampir semua tanah kecuali bertekstur berpasir, mengandung $\mathrm{K}$ total tinggi. Meskipun $\mathrm{K}$ dipegang kompleks jerapan tanah, namun sedikit yang dapat dipertukarkan. Dengan demikian, proporsi terbesar adalah tidak larut atau relatif tidak tersedia. Kalium tersedia hanya 1 hingga 2 persen dari total kalium tanah mineral.

$\mathrm{N}_{0}$ (tanpa perlakuan POC Nasa) memberikan pertumbuhan terendah pada parameter tinggi tanaman. Nitrogen $(\mathrm{N})$ merupakan sebuah unsur hara yang menetukan keberhasilan tanaman. Tanpa dilakukan pemberian POC Nasa lewat daun dan kurangnya unsur hara pada tanah dapat menghambat pertumbuhan dan perkembangan tanaman jagung manis. Tanaman yang kekurangan unsur hara $\mathrm{N}$ pada fase vegetatif akan menyebabkan tumbuh rendah (Suriatna, 
1992). Bila kekurangan N, tanaman kerdil dan pertumbuhan perakaran terhambat. Daun-daun berubah kuning atau hijau kekuningan (khlorosis, kekurangan khlorofil) dan cenderung gugur.

Waktu aplikasi pada perlakuan $\mathrm{W}_{1}$, $\mathrm{W}_{2}$ Dan $\mathrm{W}_{3}$ tidak berbeda nyata. Tinggi tanaman terbaik di tunjukkan oleh perlakuan W3 sebesar $136.73 \mathrm{~cm}$. Setyamidjaja (1986) menyatakan bahwa efisiensi pemupukan yang optimal dapat dicapai apabila pupuk diberikan dalam jumlah yang sesuai kebutuhan tanaman. Pupuk daun dapat menambah persediaan hara pada tanaman, walaupun hara diberikan relatif sedikit, tetapi bersifat kontinu. Ditambahkan oleh Nasaruddin (2010) menyatakan bahwa pemupukan lewat daun lebih cepat penyerapan haranya dibandingkan dengan lewat akar.

\section{Luas daun.}

Luas daun pada umur 6 minggu setelah tanam memberikan pengaruh yang sangat nyata antara konsentrasi $\mathrm{N}_{4}$ dengan $\mathrm{N}_{2}, \mathrm{~N}_{1}$, dan kontrol serta tidak berbeda nyata dengan $\mathrm{N}_{3}$. Hal ini disebabkan perlakuan POC Nasa dengan konsentrasi $30 \mathrm{ml} / \mathrm{L}\left(\mathrm{N}_{4}\right)$ dan $22.5 \mathrm{ml} / \mathrm{L}\left(\mathrm{N}_{3}\right)$ mampu menyediakan unsur $\mathrm{N} \quad\left(\mathrm{NH}_{3}\right)$ dan $\mathrm{S}\left(\mathrm{SO}_{2}\right)$ yang terserap lewat stomata yang berperan penting dalam proses fotosintesis. Seng (Zn) dalam kloroplas juga turut membantu asimilasi $\mathrm{CO}_{2}$ dan membuat keseimbangan $\mathrm{CO}_{2}$ dalam sel hijau daun .

Hara tanaman dalam bentuk gas, seperti $\mathrm{SO}_{2}, \mathrm{NH}_{3}$, dan $\mathrm{NO}_{2}$, dapat masuk lewat daun terutama lewat stomata. Hal ini di laporkan oleh Weigi, et al., (1962) dengan menggunakan $\mathrm{SO}_{2}$ yang dilabel $\left({ }^{35} \mathrm{SO} 2\right)$ akan cepat dimetabolis (direduksi) dan digabungkan dengan senyawa organik. Bila sulfur diberikan lewat daun atau bagian atas tanaman akan lebih cepat diserap oleh tanaman dari pada diberikan dalam bentuk $\mathrm{SO}_{4}$ pada akar. Menurut Goldsworthy dan Fisher ( 1992)daun merupakan cara perhitungan kemampuan dari tanaman untuk berfotosintesis.

Pertambahan panjang dan pertambahan luas disebabkan tumbuhan mengalami pendewasan organ-organ untuk melakukan fotosistesis dan reproduksi (Fried \& Hademous, 2006). Ditambahkan oleh Noggle dan Frizt (1983) pertumbuhan dapat ditunjukkan dengan meningkatkanya tinggi tanaman, panjang, lebar, dan luas daun. Kenaikan luas daun berkorelasi dengan kemampuan fotosistesis, sehingga berkorelasi pula dengan karbohidrat (gula, pati, dan polifruktosa). Lemak, dan minyak.Semakin luas daun tanaman jagung maka kemampuan tanaman untuk menerima cahaya meningkat.Salysbury dan Roos (1995) menyatakan bahwa semakin luas daun tanaman jagung maka penambahan $\mathrm{CO}_{2}$ untuk fotosintesis semakin meningkat sehingga mampu meningkatkan pertumbuhan tanaman.

Kekurangan unsur N, P, dan K pada fase ini berakibat pada daun jagung menyempit, memendek, daundaun tua pada jagung berwarna kuning kehijauan, tangkai daun keungguan pada bagian bawah, klorosis pada tepi daun, batang kecil dan lemah, ruas-ruas memendek dan tidak tahan terhadap hama dan penyakit (Munawar, 2011). Hal ini terlihat pada $\mathrm{N}_{0}$ (tanpa nasa) yang menghsilkan luas daun terendah.

Perlakuan waktu aplikasi pada $\mathrm{W}_{3}$ Dan $\mathrm{W}_{2}$ berbeda nyata dengan $\mathrm{W}_{1}$. Hal ini disebabkan pemberian satu kali $\left(\mathrm{W}_{1}\right)$ tidak dapat memenuhi kebutuhan hara yang perlukan dalam pertumbuhan luas daun. Selain itu pada umur jagung 6 minggu setelah tanam membutuhkan hara dan air yang relativ 
banyak untuk mendukung laju pertumbuhantanaman. Besi (Fe) dan Seng (Zn) lebih dibutuhkan pada tajuk (daun) karena berperan dalam proses fotosintesis. Ditambahkan oleh Lakitan (1993) bahwa Zn berfungsi dalam pembentukan klofil dan mencegah kerusakan pada melekul klorofil. Disamping unsur $\mathrm{Zn}$, unsur Fe juga memegang peran penting yang berhubungan dengan fotosintesis, fiksasi $\mathrm{N}^{2}$, dan respirasi. $\mathrm{Zn}$ diserap daun dalam bentuk Zink Sulfat monohidrat ( $\left.\mathrm{ZnSo}_{4}\right)$.

\section{Panjang tongkol}

Pemberian POC Nasa pada semua konsentrasi berbeda nyata dengan kontrol sedangkan diantara konsentrasi $\mathrm{N}_{1}, \mathrm{~N}_{2}, \mathrm{~N}_{3}$ Dan $\mathrm{N}_{4}$ tidak berbeda nyata. Hal ini diduga tidak adanya penambahan konsentrasi POC yang diberikan sehingga tanaman hanya menggunakan hara yang tersimpan sebagai cadangan untuk pembentukan tongkol.Panjang tongkol terbaik ditunjukkan olah konsentrasi $\mathrm{N}_{4}$ sebesar $16.27 \mathrm{~cm}$. Diduga kandungan $\mathrm{P}$ dan $\mathrm{K}$ padakonsentrasi $30 \mathrm{ml} / \mathrm{L}$ air $\left(\mathrm{N}_{4}\right)$ berperan terhadap ukuran tongkol. Hal ini sejalan dengan pendapat Sumarmo (1993), bahwa fosfor sangat dibutuhkan tanaman saat pembentukan tongkol, mengaktifkan pengisian tongkol dan mempercepat pemasakan biji. Sedangkan unsur kalium sangat dibutuhkantanaman pada saat keluarnya malai.

Mimbar (1990) menyatakan bahwa pemupukan $\mathrm{N}$ mengakibatkan meningkatnya panjang tongkol dan diameter tongkol jagung, sehingga berat tongkol meningkat. Menurut Sudjana et.al., (1991), tanaman jagung membutuhkan nitrogen sepanjang hidupnya dan sangat efektif dalam penggunaan amonium meskipun sebagian besar diambil dalam bentuk nitrat. Panjang tongkol dimulai sejak terjadinya pembuahan dan sebagian besar karbohidrat di alihkan ke bagian tongkol untuk pembentukan biji.

Tanpa pemberian POC Nasa $\left(\mathrm{N}_{0}\right)$ menunujukkan ukuran tongkol terendah. Hal ini sesuai dengan pernyataan Supriadi (2007) bahwa kekurangan unsur hara $\mathrm{P}$ tersedia dapat menyebabkan ukuran tongkol yang kecil. Hakim et al., (1986) menambahkan bahwa kekurangan unsur hara $\mathrm{P}$ tersedia menyebabkan produksi merosot.Mo (Molibdenum) jika kukurangan dapat menghambat pertumbuhan tanaman, daun menjadi pucat dan mati. Gejala defisiensi Mo umumnya terdapat pada tanah masam. Pada Tanah asam umumnya kadar Fe, Al, dan kadang-kadang Mn berlebihan (toksis). Oleh karena itu, gejala defisien Mo sering bergabung dengan adanya gejala keracunan $\mathrm{Al}^{3+}, \mathrm{Fe}^{3+}$ dan $\mathrm{Mn}^{2+}$

Panjang tongkol tidak memberikan perbedaan yang nyata diantara perlakuan $\mathrm{W}_{1}, \mathrm{~W}_{2}$, dan $\mathrm{W}_{3}$. Hal ini disebabkan waktu pemberian POC Nasa hanya sampai 6 minggu setelah tanam (3 kali aplikasi). Sehingga pada saat pembentukan tongkol tidak ada lagi pasokan hara. Kekurangan $\mathrm{N}$ atau adanya gangguan metabolisme $\mathrm{N}$ pada kisaran waktu tertentu akan membatasi ukuran tongkol. Oleh karena itu untuk memperoleh produksi tongkol yang tinggi unsur hara $\mathrm{N}$ harus tersedia dengan cukup selama fase pertumbuhannya. Seperti dikemukakan oleh Lingga (2003), bahwa dalam penyemprotan pupuk daun ada beberapa hal yang perlu diperhatikan yaitu selain jenis pupuk daun yang digunakan, kandungan har apupuk daun dan konsentrasi larutan yang dberikan, juga waktu penyemprotan. 


\section{Berat tongkol berkelobot}

Perlakuan POC Nasa pada semua konsetrasi tidak berbeda nyata dan hanya berbeda nyata dengan kontrol. Hal ini disebabkan waktu pengisian tongkol jagung terutama dipengaruhi oleh ketersediaan hara yang diterima oleh tanaman. Hara yang diterima akan digunakan untuk membentuk asmilat, dimana asimilat akan meningkat selama pengisian dan pertumbuhan tongkol. Pengisian dan pertumbuhan tongkol akan maksimal apabila karbohidrat dalam tanaman cukup tersedia. Konsentrasi $30 \quad \mathrm{ml} / \mathrm{L}$ air (N4) memberikan berat tongkol terbaik. Hal ini selaras dengan hasil penelitian Tabri (2011) pemberian dengan konsentrasi tertinggi $(5 \mathrm{~g} / \mathrm{lt}$ air $)$ memberikan berat bobot tongkol (7.15 ton/ha) terbaik dibandingkan dengan konsentrasi terendah dibawahnya. Nugroho et. al (1999), menyatakan bahwa peningkatan bobot tongkol pada tanaman jagung manis seiring dengan meningkatnya efisiensi proses fotosintesis maupun laju translokasi fotosintat ke bagian tongkol.

Peran unsur hara $\mathrm{P}$ dalam pembentukan bunga mempengaruhi pembentukan dan ukuran tongkol, karena tongkol merupakan perkembangan dari bunga betina. Hal ini didukung oleh pernyataan Sutejo (1995)bahwa untuk mendorong pembentukan bunga dan buah sangat diperlukan unsur $\mathrm{P}$ tanaman. Peranan $\mathrm{Cu}$ pada POC Nasa dapat memberikan suplai hara terhadap produksi tanaman jagung manis. Menurut Roesmarkam dan Yuwono (2002) $\mathrm{Cu}$ ikut berperan dalam metabolisme protein dan karbohidrat.

Berat tongkol terendah terlihat pada $\mathrm{N}_{0}$. Hal ini disebabkan tidak adanya suplai hara seperti kekurangan unsur $\mathrm{N}, \mathrm{P}$, dan $\mathrm{k}$ serta unsur mikro selama fase vegetatif. Salah satu unsur mikro yang memberikan bobot tongkol menjadi rendah adalah $\mathrm{Cu}$.Apabila kekurangan $\mathrm{Cu}$ maka sintesa protein akan terganggu sehingga pembungaan dan pembuahan menjadi terganggu, sehingga pembentukan biji pada tongkol juga terganggu.

Waktu aplikasi tidak berdeda nyata terhadap berat tongkol berkelobot. Hal ini disebabkan waktu aplikasi penyemprotan tidak maksimal. Seperti yang dikemukakan oleh Lingga (2003), bahwa dalam penggunaan pupuk cair utamanya yang disemprotkan melalui daun, ada beberapa hal yang perlu diperhatikan selain jenis pupuk daun yang digunakan, kandungan hara pupuk dan konsentrasi larutan yang diberikan, juga waktu penyemprotan.

\section{KESIMPULAN DAN SARAN}

\section{Kesimpulan.}

1. Konsentrasi POC Nasa berpengaruh nyata terhadap pertumbuhan dan produksi tanaman jagung manis. Konsentrasi $\mathrm{N}_{4}(30 \mathrm{ml} / \mathrm{L}$ air $)$ merupakan konstrasi terbaik terhadap peningkatan produksi berat tongkol berkelobot sebesar $286.41 \mathrm{~g}$ / tanaman.

2. Waktu aplikasi berpengaruh nyata terhadap tinggi dan luas daun pada umur 6 minggu setelah tanam. Waktu aplikasi 2,4, dan 6 MST $\left(\mathrm{W}_{3}\right)$ merupakan waktu aplikasi terbaik terhadap pertumbuhan dan produksi jagung manis.

3. Kombinasi konsentrasi POC Nasa dan waktu aplikasi tidak terjadi perbedaan yang nyata terhadap semua parameter yang diamati.

4. Pemberian POC Nasa $15 \mathrm{ml} / 5 \mathrm{~L}$ air/plot mampu memberikan perubahan terhadap $\mathrm{pH}$ tanah dari 4.7 menjadi 5.4., $\mathrm{N}_{\text {organik }}$ dari 0.09 $\%$ menjadi $0.11 \%, \mathrm{P}_{\text {tersedia }}$ dari 20.2 menjadi 16.9 Ppm, dan $\mathrm{K}_{\text {tersedia }}$ dari 73 menjadi $83 \mathrm{Ppm}$. 


\section{DAFTAR PUSTAKA}

Gaspers, V. 1991. Metode Perancanaan Percobaan. Penerbit CV. Amico, Bandung.

Goldsworthy, P. R dan N. Fisher. 1992. Fisologi Tanaman Budidaya Tropik. Gadjah Mada University Press. Yogyakarta.

Gomez, K. A., dan A. A. Gomez. 1995. Prosedur Statistik untuk Penelitian Pertanian Terjemahan dari Statistical Procedures for Agricultural Research. Terjemahan E. Sjamsuddin dan J.S. Baharsjah. Universitas Indonesia Press, Jakarta. Edisi Kedua.

Hakim, Nyakpa dan A.M Lubis. 1986. Dasar-dasar Ilmu Tanah. Universitas Lampung, Lampung

Hanafiah, K.A 2003. Rancangan Percobaan :Teori dan Aplikasi. Rajawali Pers, PT Raja Grafindo Persada, Jakarta.

Hardjowigeno, S. 1997. Ilmu Tanah. Jakarta : Mediyatama Sarana Perkasa.

Husin, M, N. 2012. Pengaruh pupuk organic cair nasa terhadap nitrogen bintil akar Dan produksi Macroptilium Atropurpureum.

Isnaini, S. 2005. Kandungan Kalium dan Amonium Tanah dan Serapanya serta Hasil Padi akibat perbedaan Pengolahan tanah yang dipupuk nitrogen dan kalium Pada Tanah Sawah. Jurnal Ilmu-Ilmu Pertanian Indonesia; 7:1:23-24.

Jumin, H.B. 2008. Dasar-Dasar Agronomi. Jakarta. PT Rajagrafindo Persada.

Lingga. 1992. Petunjuk Penggunaan Pupuk. Penebar Swadaya. Jakarta hal 9-10.

Mayadewi,N.A. 2007. Pengaruh Jenis Pupuk kandang dan Jarak Tanam terhadap Pertumbuhan Gulma dan
Hasil Jagung Manis. Jurnal Agritrop, 26 (4) : 153 - 159.

Mimbar, S.M. 1990. Pola Pertumbuhan dan Hasil Jagung Kretek Karena Pengaruh Pupuk N. Jurnal Agrivita 13(3): 82-89.

Munawar, A. 2011. Kesuburan Tanah dan Nutrisi Tanaman. IPB Pres

Nasaruddin, 2010 . Dasar-dasar Fisiologi Tanaman. Fakultas Pertanian Universitas Hasanuddin dan Yayasan Forest Indonesia, Jakarta.

Latuamury, N. (2017). Pengaruh Dosis Pemberian Bekatul Terhadap Perubahan Sifat Kimia Tanah Sawah Di Dukuh Pranti Desa Srihardono Kecamatan Pundong Kabupaten Bantul. MEDIAN, 9(2), 29-34.

Nursyamsi, D., K.Idris, S. Sabihan, D.A. Rachim, dan A Sofyan, 2008. Pengaruh Asam Oksalat, $\mathrm{Na}+$, $\mathrm{NH} 4+$, dan $\mathrm{Fe} 3+$ terhadap Ketersediaan K tanah, Serapan N, $\mathrm{P}$, dan $\mathrm{K}$ Tanaman, serta Produksi Jagung pada Tanah-tanah yang didominasi Smektit. Jurnal Tanah dan Iklim No. 28: 69-82.

PT Nasa, 2005. Pupuk Organik Cair Nasa. Natural Nusantara. Indonesia.

Pusat Penelitian Pengembangan Tanah dan Agroklimat (PPTA). 2003. Klasifikasi Tanah-Tanah di Indonesia. PPTA, Bogor.

Rosmarkam, A dan N. W. Yuwono. 2002. Ilmu Kesuburan Tanah. Kanisius. Yokyakarta. 224 hal.

Salisbury, B. F., C. W. Ross, 1995. Plant Physiology. (Fisiologi Tumbuhan terjemahan Diah R. Lukman dan Sumaryono) jilid 3. Penerbit ITB, Bandung.

Saptarini, Widayati dan Sari. 1993. Membuat Tanaman Cepat Berbuah. P.S. Penebar Swadaya. Jakarta. 80 hal. 
Sangadji, Z. (2018). Pertumbuhan Dan Hasil Tanaman Sawi Pada Bebarapa Jenis Bokashi (Growth And Produce The Mustard At Various Type Bokashi).

Sudjana, A., A. Rifin, dan M. Sudjadi. 1991. Jagung. Buletin Teknik No.

3. Badan Penelitian dan Pengembangan Pertanian Balai Penelitian Tanaman Pangan Bogor. Jl. Tentara Pelajar 3 A Bogor.

Sumarmo, M. S., 1993. Sistem unsur hara tanaman. Universias Brawijaya. Malang.

Supriadi, S. 2007. Kesuburan tanah di Lahan Kering Madura. Embryo. Jurnal Ilmu-Ilmu Pertanian. Vol. 4:2:124-131.

Suriatna, S., 1992. Pupuk dan Pemupukan. Jakarta: Mediatam Sarana Perkasa.

Sutejo, M.M. 2002. Pupuk dan Cara Pemupukan. Jakarta : Rineka Cipta
Sutejo, M.M. 1995. Pupuk dan Cara Pemupukan. Rineka Cipta, Jakarta.

Tisdale, S. L., W. L. Nelson and J. D. Beaton. 1985. Sosil Fertility and Fertilizers. Fourth Edition. Mac Millan Publishing Company, New York. 754 p.

Toha, Faisal H, Dahlan, dan Kaharuddin. 2007. Pengaruh Penggunaan Dosis Pupuk Bokashi Kotoran Sapi terhadap Pertumbuhan dan Produksi Tanaman Jagung. Jurnal Agrisistem. Vol.3 No. 1.

Wahyudi P, Mudji S, dan Tatik W. 2013. Pengaruh Beberapa Macam Kombinasi Pupuk Organik dan Nonorganik Terhadap Pertumbuhan dan Hasil Tanaman Jagung Manis. Jurnal Produksi Tanaman Vol. 1 No. 3. ISSN : 2338-3976 Jurusan 